\title{
The implementation of student team achievement division and picture series on improving the speaking skill of the 3rd grade students of cipta dharma elementary school in academic year 2016/2017
}

\author{
Nengah Dwi Handayani ${ }^{1, *}$ and Dewa Gd. Ag. Gana Kumara, ${ }^{2, *}$ \\ ${ }^{1,2}$ English Education Study Program, Mahasaraswati University, Denpasar, Bali, Indonesia
}

\begin{abstract}
The aim of this research was to find out whether or not the Speaking Skill of the $3^{\text {rd }}$ grade students of Cipta Dharma Elementary School could be improved through Student Team Achievement Division (STAD) and Picture Series in Academic Year 2016/2017. This Research used a Classroom Action Research with the total 36 students taken as subject. The result was, in Pre Cycle 52.78\% (19 students); in Cycle 1 $69.44 \%$ (25 students); and in Cycle $288.89 \%$ (32 students) reached the minimum completeness learning mastery. Based on the result, it could be concluded that the subject's Speaking Skill could be improved the implementation of STAD and Picture Series.
\end{abstract}

Key words:Speaking skill, STAD, Picture series

\section{Introduction}

One of the four main skills in English is Speaking Skill. [14] states that speaking is one of the most difficult aspects for students to master. Speaking skills is one aspect that is quite difficult to master because it is associated with several elements of language that must be mastered namely grammar, vocabulary, pronunciation and fluency.

English is currently defined as one of the local content subjects taught in schools. [6] states good speaking activities should be extremely enggaging for the students. It implies that students should be fully engaged in teaching and learning activities that are associated with the improvement of speaking skills. It will also directly challenge teachers to create an interesting and interactive learning process.

One of the techniques that can be used in speaking skill learning is the Student Team Achievement Division (STAD). STAD is one type of cooperative learning (cooperative learning). This STAD is applied by dividing the pupils into groups. What is characteristic of the STAD is that group divisions are based on student achievement in the class itself.

\footnotetext{
*Corresponding author: ndwihandayani@gmail.com
} 
Besides designing interesting and interactive learning, teachers are also required to be creative and innovative in developing learning media. One of the media that can be used in teaching speech skills is the series image (Picture Series). A series image is a series of related images and forms a story or a cascading explanation.

Based on the initial observations that have been done at Cipta Dharma Denpar Primary School, it was found that the students, especially the $3 \mathrm{rd}$ grade, experienced the same thing in expressing something in English. Teachers have been trying to apply some learning techniques and approaches, but speaking skills of grade 3 students of Cipta Dharma Elementary School were still under minimal mastery criteria.

Based on the problems that occur above, Researchers are highly interested in conducting a study on speaking skill. Therefore, this research will focus on Implementation of Student Team Achievement Division and Picture Series as an effort to improve English Speaking Skills of the 3rd Grade Students of Cipta Dharma Elementary School. The purpose of this research are: 1) to know whether or not English Speaking Skills of Grade 3 students of SD Cipta Charma is enhanced by the application of STAD and Picture Series. 2) to know the response of 3rd Grade Students of SD Cipta Dharma Denpasar towards the application of STAD and Picture Series in an effort to improve English Speaking Skills.

\section{Method}

\subsection{Research Design}

This research made use of Classroom Action Research. The procedures of this study includedInitial Reflection (IR), Planning (P), Actions (A), Observation (O), Reflection (R) and Revised Planning (RP) performed in cycle form.

\subsection{Participants}

The subject of the study was the $3^{\text {rd }}$ grade Students of Cipta Dharma Elementary School in academic year 2016/2017. There were 36 students taken as the subject of this study. Based on the initial observations that have been done, it was found that the students experienced difficulties in expressing something in English. Teachers have been trying to apply some learning techniques and approaches, but most of the stuents' speaking skills were still under minimal passing grade.

\subsection{Measures}

The data gathered from the pre test and post tests were analyzed using formula of :

$$
M=\frac{\sum X}{N}
$$

In which the total score of the students was divided by the total number of the students, meanwhile, the result of questioanire was analyzed using rating scale 1 to 4 to figure out the students'responses towards the implementation of STAD and Picture Series.

\subsection{Procedure and data analysis}

IR was conducted in the form of a preliminary test that aimed to determine the initial ability of research subjects. $\mathrm{P}$ was a plan that was contained in the form of lesson plan 
based on the needs of research. A was the action of this study which consisted of the steps of learning. After doing the action, proceed with observing $(\mathrm{O})$ and reflecting $(\mathrm{R})$ by doing post test. The post tests were carried out by the end of each cycle. The test were analysed by using a speaking scoring rubric.

\section{Results and Discussion}

The Initial Reflection which was in the form of pre test was conducted in order to know the students'pre-existing speaking skill. The result of the questionnaire was 67.03. The test was conducted by asking students to tell about themselves infront of the class. Most of the subject under study were still shy and doubt of what the were saying.

After figuring out the result of the pre test, it was continued by planning the lesson plan. The lesson plan was designed by using STAD and Picture Series. After having a well prepared leeson plan and materials, the research was continued by conducting a teaching learning activites of the cycle 1 which consisted of two sessions. By the end of the last session of this cycle, the post test 1 was administered. The result of the post test was 77.67. There was an improvement of the subject's speaking skill based on the result of the post test. The students were active in doing their learning activities, but there were some of them were still confused and shy of sharing their ideas with the group during the class. The low achievement students were not really active in the group discussion using Pictures Series.

Based on the result of the post test 1 , then it continued by planning the lesson followed by applying the plan for cycle 2 . This cycle also consisted of two session ended by gathering the post test 2 . The result of post test 2 was 82.36 . The was a significant improvement from post test 1 to post test 2 . The students were very active and really enjoyed the learning activites. Students who were at excellent and good achievement could assisst students who were sufficient. Besides, the questionnaire was also conducted at the end of this cycle.

The data of questionnaire were measured by using scale 1 to 4 . The rusult of the questionnaire showed that $85.62 \%$ strongly agreed, $10.99 \%$ agreed, $03.16 \%$ neither, and $00.23 \%$ disagreed with the implementation of STAD and Picture Series in improving speaking.

Based on the result above, it could be concluded that:1) The Speaking Skill of the $3^{\text {rd }}$ grade students of Cipta Dharma Elementary School could be improved through the implementation of STAD and Picture Series in academic year 2016/2017. 2) The subject under study gave a positive response on the implementation of STAD and Picture Series in improving Speaking SKill

\section{Conclusion}

The Result of this research showed the mean score of pre test, post test 1 and post test 2 were $67.03,77.67,82.36$. And the result of the questionnaire showed $85.62 \%$ strongly agreed, $10.99 \%$ agreed, $03.16 \%$ neither, and $00.23 \%$ disagreed with the implementation of STAD and Picture Series in learning Speaking.

\section{References}

1. D. Ary, L. C. Jacobs, S. Sorensen, A. Razavieh, Introduction to Research in Education, (Wadsworth, California, 2010).

2. H. D. Brown, Language Assessment, (Longman, New York, USA, 2004). 
3. L. Cameron, Teaching Language to Young Learners. (Cambridge University, New York, 2001).

4. R. Carter, The new grammar teaching. In R Carter (Ed.), Knowledge about language and the curriculum (Hodder \& Stoughton, London, 104-121, 1990).

5. I. K. Ghosn, ELT Journal 6 (2) (2002).

6. J. Harmer, The Practice of English Language Teaching, (Longman, Cambridge, 2007).

7. S. Hawanti, International journal of pedagogies and learning 9 (2) (2014).

8. K. Hayriye, The Internet TESL Journal XII (11) (2006).

9. W. Jolliffe, Cooperative Learning in the Classroom (Paul Chapman Publishing, London, 2007).

10. P. J. Krish, The Internet TESL Journal VII (7) (2001).

11. Mantra, et al. International Journal of Linguistics, Language and Culture (IJLLC) 2 (2) (2016).

12. I K. Natasa, The Internet TESL Journal XII (11) (2006).

13. L.S. Norton, Action Research in Teaching and Learning (Routledge, Oxford, 2011).

14. L. Pollard, Teaching English : A book to Help You through Your First TwoYears in Teaching (Cambridge University Press, London, 2008).

15. J. C. Richard, W. Renandya, Methodology in Language Teaching : An Anthology of Current Practice (Cambridge University Press, . Cambridge, 2002).

16. G. Shahini, A. M. Riazi, A PBLT Approach to Teaching ESL Speaking, Writing, and Thinking Skills. Retrieved April 15, 2017, from http://eltj.oxfordjournals.org/content/65/2/170.

17. I.A. Md. Sri Widiastuti, The ASIAN EFL Journal 3 (2016).

18. Thornbury, S. How to Teach Speaking (Pearson Longman, USA, 2005). 